\title{
Relationship between Pain and Serum Ferritin Levels in Adult Transfusion-Dependent Thalassemia
}

\author{
Shenny Dianathasari Santoso, ${ }^{1}$ Uni Gamayani, ${ }^{1}$ Asep Nugraha Hermawan, ${ }^{1}$ Pandji Irani \\ Fianza, ${ }^{2}$ Aih Cahyani, ${ }^{1}$ Lisda Amalia, ${ }^{1}$ Yusuf Wibisono, ${ }^{1}$ Ramdan Panigoro ${ }^{3}$ \\ ${ }^{1}$ Department of Neurology, Faculty of Medicine, Universitas Padjadjaran/Dr. Hasan Sadikin General Hospital, \\ Bandung, Indonesia, ${ }^{2}$ Department of Internal Medicine, Faculty of Medicine, Universitas Padjadjaran/ \\ Dr. Hasan Sadikin General Hospital, Bandung, Indonesia, ${ }^{3}$ Research Center for Medical Genetics, \\ Faculty of Medicine, Universitas Padjadjaran, Bandung, Indonesia
}

\begin{abstract}
Patients with transfusion-dependent thalassemia (TDT) may experience an increase in ferritin due to shorter erythrocyte lifespan and lysis, as well as side effects of transfusion. Increasing ferritin can cause various complications, including pain, which can develop into chronic pain and interfere with life quality. This study aims to determine the relationship between pain and serum ferritin levels in adults with TDT. This study was an analytical observational study using a cross-sectional design on adult TDT patients with pain who came to the Hemato-Oncology Clinic of Dr. Hasan Sadikin General Hospital Bandung. This research was conducted from March to June 2021. All subjects were assisted to fill out the Indonesian version of the Brief Pain Inventory Short Form (BPI-SF) questionnaire before transfusion. Ferritin levels in the last three months were obtained from medical records. If more than three months, serum ferritin levels were examined. Ferritin levels and BPI-SF scores were then correlated using the Pearson test. The study was conducted on 51 adult TDT patients with pain, and the average value of ferritin levels in research subjects is $5081 \pm 2929 \mathrm{~g} / \mathrm{L}$. There was a relationship between pain (the dimensions of pain interfere with life on the BPI-SF score) and an increase in ferritin levels $(\mathrm{p}=0.042, \mathrm{r}=0.29)$. The results showed there is a relationship between pain and serum ferritin levels. Regular consumption of iron chelation tablets can reduce ferritin levels and improve the quality of life for adults with TDT.
\end{abstract}

Keywords: Ferritin, pain, thalassemia

\section{Hubungan Nyeri dengan Kadar Feritin Serum pada Penyandang Transfusion-dependent Thalassemia Dewasa}

\begin{abstract}
Abstrak
Penyandang transfusion-dependent thalassemia (TDT) dapat mengalami peningkatan feritin akibat umur eritrosit yang lebih pendek dan mudah lisis, serta efek samping terhadap pemberian transfusi. Peningkatan feritin tersebut dapat menyebabkan berbagai komplikasi di antaranya nyeri yang dapat berkembang menjadi nyeri kronik dan mengganggu kualitas hidup. Penelitian ini bertujuan mengetahui hubungan nyeri dengan kadar feritin serum pada penyandang TDT dewasa. Penelitian dengan observasional analitik menggunakan rancangan potong lintang pada penyandang TDT dewasa dengan nyeri yang datang ke Klinik Hemato-Onkologi RSUP Dr. Hasan Sadikin Bandung. Penelitian dilakukan dari Maret hingga Juni 2021. Seluruh subjek dilakukan pendampingan untuk mengisi kuesioner Brief Pain Inventory Short Form (BPI-SF) versi Indonesia sebelum transfusi. Kadar feritin dalam tiga bulan terakhir didapatkan dari rekam medis dan bila lebih dari tiga bulan dilakukan pemeriksaan kadar feritin serum. Kadar feritin dan skor BPI-SF kemudian dikorelasikan menggunakan Uji Pearson. Penelitian dilakukan kepada 51 penyandang TDT dewasa dengan gejala nyeri dan didapatkan nilai rerata kadar feritin pada subjek penelitian adalah $5081 \pm 2929 \mu \mathrm{g} / \mathrm{L}$. Hasil penelitian memperlihatkan terdapat hubungan antara nyeri (dimensi efek nyeri terhadap kehidupan) dan peningkatan kadar feritin ( $\mathrm{p}=0,042 ; \mathrm{r}=0,29)$. Hasil penelitian menunjukkan terdapat hubungan antara nyeri dan kadar feritin serum. Konsumsi tablet kelasi besi secara rutin dapat menurunkan kadar feritin dan memperbaiki kualitas hidup penyandang TDT dewasa.
\end{abstract}

Kata kunci: Feritin, nyeri, thalassemia

Received: 27 October 2021; Revised: 24 December 2021; Accepted: 30 December 2021; Published: 31 December 2021 Correspondence: Dr. Uni Gamayani, dr., Sp.S.(K). Department of Neurology, Faculty of Medicine, Universitas Padjadjaran/ Dr. Hasan Sadikin General Hospital. Jln. Pasteur No. 38, Bandung 40161, West Java, Indonesia. E-mail: gamayani@yahoo.com 


\section{Introduction}

Thalassemia is a blood disorder disease that occurs due to decreased or lost synthesis of one or more globin chains. This disease is hereditary autosomal recessive due to mutations in the globin-forming gene..$^{1,2}$ Thalassemia can cause various transfusion-dependent thalassemia (TDT) complications, including pain. TDT patients need regular transfusions (2-6 weeks) to survive..$^{1,3}$ Recent studies have shown an increase in pain in thalassemia patients, while the assessment and management of pain in thalassemia patients are still neglected. ${ }^{4}$

People with TDT can experience iron accumulation in the body through several mechanisms. They include shorter erythrocyte lifespan, lysed erythrocytes, and transfusion side effects, thus requiring an iron binder (chelate); iron can be excreted through urine and feces. This accumulation causes an increase in NTBI, which is reflected in ferritin levels in the blood. NTBI is a labile iron that can cause an increase in ROS and then activates transient receptor potential ankyrin 1 (TRPA1) and transient receptor potential vanilloid 1 (TRPV1), which can increase pain sensitization. An increase in NTBI causes an increase in bone resorption and thinning of the bone cortex so that osteopenia and osteoporosis can occur, which can cause fractures and compression of the surrounding nerves. Iron accumulation can also occur in muscles and cause muscle damage due to increased reactive oxygen species (ROS) and then trigger peripheral and central pain sensitization. In addition, iron deposits can occur in the synovial tissue and release free radical products that cause synovial destruction in the joints. ${ }^{5,6}$ The accumulation of iron in the blood can be monitored by measuring the ferritin level in the blood. The advantages of the serum ferritin test are that it is easy to assess quickly, measures the adequacy of iron chelation therapy, and can show long-term outcomes. ${ }^{7}$

Pain is a multidimensional sensation influenced by intensity, quality, location, frequency, and psychosocial. Acute pain can directly impact the patient's quality of life, while chronic pain can be adapted to pain to experience pain tolerance. However, their quality of life can be disrupted due to long-lasting pain. ${ }^{8}$ The purpose of this study is to determine the relationship between pain and serum ferritin levels in adults with TDT using the BPI-SF questionnaire. This tool can assess pain in the thalassemia patient that is easy to apply and determine how the impact of pain on the quality of life of people with thalassemia.

\section{Methods}

The subjects in this study were people with transfusion-dependent thalassemia with pain who regularly came to the Hemato-Oncology Clinic, Dr. Hasan Sadikin General Hospital Bandung, who met the inclusion criteria. The inclusion criteria for the subjects were patients diagnosed with thalassemia with pain who underwent routine transfusions at the HematoOncology Clinic, Dr. Hasan Sadikin General Hospital Bandung with high ferritin levels, and is 18 years old and willing to participate in the study. Exclusion criteria were patients with confirmed pain due to fractures/other diseases. Approval of research ethics was obtained from the ethics committee Universitas Padjadjaran Bandung under the ethical clearance number 198/UN6. $\mathrm{KEP} / \mathrm{EC} / 2021$.

This study was an analytical observation using a cross-sectional design conducted from March to June 2021. Ferritin levels in the last three months were obtained from medical records. Serum ferritin levels were examined and not taken from the medical history if the patients did not have it for more than three months. Subjects filled demographic data was filled in, and pain screening was carried out on the subject, with assistance using the BPI-SF questionnaire, which had been validated in Indonesian before transfusion. The BPI-SF was a multidimensional pain assessment tool suitable for assessing chronic pain. The pain components considered were pain intensity, and pain interferes with life. The pain scale to describe pain intensity was using the Numeric Rating Scale (NRS), with score intervals were 1-3 (mild pain), 4-7 (moderate pain), and 8-10 (severe pain). BPI-SF scores before transfusion were correlated with serum ferritin levels using the Pearson test.

\section{Results}

This study is conducted on 51 people diagnosed with transfusion-dependent thalassemia with pain symptoms who regularly come to the Hemato-Oncology Clinic, Dr. Hasan Sadikin General Hospital Bandung. Demographic data are obtained through interviews after signing 
the informed consent form. The demographic distribution of the subjects is described in Table 1.

The mean age of the subjects were young adults, i.e., 25.5 \pm 7.2 years, and most of them were women (75\%). Most (86\%) do not work with daily activities at home and go to school. The duration of being diagnosed with thalassemia ranged from 3-40 years with a mean of $19.5 \pm 6.4$ years. Most subjects took iron chelation tablets regularly, with the most consumed chelation drug being deferasirox (55\%). Three subjects did not take iron chelation tablets because one subject was breastfeeding. In the previous examination, two subjects showed ferritin results of less than 1,000 $\mathrm{g} / \mathrm{L}$, so they did not need iron chelation tablets.

The results of the BPI-SF score for adults with TDT, in Table 2, show that the highest pain intensity before transfusion was moderate pain in $43(84 \%)$, mild pain in $6(12 \%)$, and severe pain in $2(4 \%)$ subjects. The average value of ferritin levels in the subjects of this study was $5,081 \pm 2,929 \mathrm{~g} / \mathrm{L}$.

\section{Table 1 Description of the Characteristics} of Research Subjects

\begin{tabular}{lc}
\hline Characteristics & n=51 (\%) \\
\hline Age (years) & $25.5 \pm 7.2$ \\
Mean \pm Std & $18-43$ \\
Range (min-max) & \\
Gender & $13(25)$ \\
Male & $38(75)$ \\
Female & \\
Education & $7(14)$ \\
Elementary school & $12(23)$ \\
Junior high school & $28(55)$ \\
Senior high/vocational school & $4(8)$ \\
College & \\
Profession & $44(86)$ \\
Unemployed & $7(14)$ \\
Employed & \\
Length of diagnosed thalassemia & \\
(years) & \\
Mean \pm Std & $19.5 \pm 6.4$ \\
Range (min-max) & $3-40$ \\
Iron chelation tablet & \\
Not taking iron chelation tablets & $3(6)$ \\
Deferasirox & $28(55)$ \\
Deferiprone & $20(39)$ \\
\hline
\end{tabular}

Table 2 Description of BPI and Ferritin of Research Subjects

\begin{tabular}{lc}
\hline Variables & $\mathbf{n = 5 1}$ \\
\hline Pain intensity & \\
Median & 5.00 \\
$\quad$ Range (min-max) & $1.8-7.5$ \\
Effects of pain on life & \\
$\quad$ Median & 2.75 \\
Range (min-max) & $0-8.1$ \\
Ferritin level ( $\mu$ g/L) & \\
Average \pm SD & $5,081 \pm 2,929$ \\
$\quad$ Range (min-max) & $334.3-12,937.7$ \\
Decrease in pain intensity & \\
Average \pm SD & $-4.4 \pm 2.2$ \\
Range (min-max) & $-7.5-1.8$ \\
\hline
\end{tabular}

Note: the normal value of ferritin in male: $10-220 \mu \mathrm{g} / \mathrm{L}$, female: $10-85 \mu \mathrm{g} / \mathrm{L}^{4}$

The location of the pain was experienced mainly in the lower back 22 (43\%), the second most common location was the knee 17 (33\%), 12 (24\%) complained of more than one location in the body, such as in the joints of the fingers and toes, calves, ankles, ankles, heels, and shoulders

The results of the Pearson test between the variables of pain interferes with life and ferritin levels obtained $\mathrm{p}=0.042$ ( $\mathrm{p}<0.05)$, which shows a significant correlation (Table 3 ). The $\mathrm{r}$ value is 0.29 with a positive correlation direction and weak strength (not close). On the other hand, the results of the Pearson test between the variables of pain intensity and ferritin levels obtained $\mathrm{p}=0.332$ ( $\mathrm{p}>0.05)$, which shows an insignificant correlation. The correlation coefficient (r) value is -0.14 with a positive correlation direction and

\section{Table 3 Relationship between Pain Intensity and Pain Interferes with Life with Ferritin Levels}

\begin{tabular}{lcc}
\hline Variables & r & p Value \\
\hline $\begin{array}{l}\text { Correlation of pain } \\
\quad \text { interferes with life with }\end{array}$ & 0.9 & 0.042 \\
$\quad$ ferritin levels & & \\
$\begin{array}{l}\text { Correlation of pain } \\
\quad \text { intensity with ferritin }\end{array}$ & -0.14 & 0.332 \\
$\quad$ levels & & \\
\hline Note: ${ }^{*}$ Pearson test, $\mathrm{p}<0.05$ significant &
\end{tabular}


weak strength.

\section{Discussion}

The ferritin results obtained in this study indicate that adult TDT patients at Dr. Hasan Sadikin General Hospital Bandung are in a state of hyperferritinemia. Ferritin levels of more than $1,000 \mathrm{~g} / \mathrm{L}$ are at risk for complications, including arthropathy. ${ }^{9}$ Iron accumulation can occur in thalassemia due to easy lysis of erythrocytes. This lysed erythrocyte will cause iron accumulation, resulting in an increase in free iron in the form of NTBI in the cytosol.4,7 This NTBI is labile and releases ROS, which causes TRPA1 and TRPV1 to increase pain sensitization. ${ }^{10}$ TRPA1 and TRPV1 are nonselective cations. The channel is expressed mainly in unmyelinated $\mathrm{C}$ nerve fibers, which act as detectors and integrators of pain stimuli. The role of TRPV1 and TRPA1 in thalassemia-related pain is thought to be associated with arthritis. The two molecules can be activated in sensory neurons, chondrocytes, and synoviocytes. ${ }^{11}$

Iron accumulation can also occur in muscles and cause muscle damage due to increased ROS. ${ }^{12}$ An increase in NTBI causes an increase in bone resorption and thinning of the bone cortex so that osteopenia and osteoporosis can occur, which, if left unchecked, will cause fracture and compression of the surrounding nerves. In addition, iron deposits can occur in the synovial tissue and release free radical products that cause synovial destruction in the joints. Joints are innervated by sensory and sympathetic nerve fibers, which are sensitive to nociceptive stimuli, and function as vasoregulator and proprioceptive. Fibers are activated by joint movement, whereas $\mathrm{A} \beta$ and $C$ fibers are activated by noxious mechanical, thermal, and chemical stimuli and inflammatory mediators. Joint nociceptors are generally inactive but become activated when joint damage occurs, as in arthritis. These nociceptors then cause peripheral and central sensitization. The discrepancy between the intensity of pain and the level of joint damage is one of the causes of this pain sensitization. ${ }^{6}$

Pain in thalassemia is associated with musculoskeletal involvement with a wide variety of symptoms. ${ }^{13}$ The most common musculoskeletal pain complaints are arthritis and low back pain. ${ }^{4}$ Iron accumulation causes delays in osteoid maturation and bone mineralization. Decreased bone mass in thalassemia often occurs in the vertebral column. It manifests as spinal deformity, bone marrow compression, vertebral collapse, and intervertebral disc degeneration..$^{14-16}$ Formation of matrix metalloproteinases that can underlie the development of arthritis. ${ }^{17}$ The knee joint is also a site frequently involved in musculoskeletal pain, as it is the part of the body that supports more weight. The features found on ultrasonography of the knee joint are synovitis, effusion, and metaphyseal dysplasia. The ankle joint is prone to inflammation that damages the joint cartilage, also known as thalassemic osteoarthropathy. ${ }^{18,19}$

Pain assessment in the subjects of this study used the BPI-SF questionnaire. The BPI questionnaire was first developed for cancer patients but is now widely used for nonmalignant diseases, including thalassemia. This questionnaire can be completed by the patient or by the examiner. The pain components assessed are pain intensity, and pain interferes with life, so this questionnaire is a multidimensional assessment tool suitable for assessing chronic pain. Uni-dimensional pain assessment tools such as Numeric Rating Scale (NRS), Verbal Rating Scale (VRS), Visual Analogue Scale (VAS), and Faces Pain Scale are good in assessing acute pain. They describe pain intensity and are easy to use for pain evaluation. However, evaluating chronic pain has many limitations because it is influenced by many factors, including pain tolerance, pain experience, and emotions. ${ }^{20}$ It consists of 15 questions with a sensitivity of $79.4 \%$. The advantage of BPI-SF is that it is easier to do, it only takes five minutes, and it can evaluate therapy. ${ }^{21-23}$

Pain is a multidimensional sensation influenced by intensity, quality, location, frequency, and psychosocial. The degree of pain must also be considered to the frequency of pain because patients with mild or moderate pain, but chronic, can interfere with the patient's quality of life on a par with patients with acute pain lasting 1-2 days. Pain is influenced by biological and psychosocial factors, including pain tolerance. ${ }^{1}$ Acute pain can directly affect the patient's quality of life. In contrast, chronic pain can occur adaptation to pain so that patients experience pain tolerance, but their quality of life can be disrupted due to long-lasting pain. ${ }^{24}$

The subjects in this research may have experienced tolerance to pain because thalassemia has been suffered for a long time. Subjects felt 
the impact of pain improvement on life after transfusion compared to the intensity of pain, primarily moderate. Assessment of pain that interferes with life in people with thalassemia is currently being carried out for better evaluation and management. ${ }^{24}$

Research using the NRS may not show improvement in treatment because the NRS does not fully describe the pain experienced by the patient. ${ }^{25}$ Important to assess, as found in the BPI-SF questionnaire. This questionnaire can be more effective in determining the improvement of pain experienced by patients with chronic pain than setting pain intensity with NRS alone. This questionnaire assesses how much pain interferes with daily activities, mood, ability to walk, work relationships with others sleep. And the comfort of life. ${ }^{26,27}$

This study indicates a relationship between pain (the dimensions of pain interfere with life on BPI-SF) and serum ferritin levels. Pain intensity analysis test with ferritin levels was insignificant ( $p>0.05$ ). This result is similar to a previous study by the Thalassemia Clinical Research Network. ${ }^{1}$ It could be due to $94.1 \%$ of subjects taking iron chelation tablets regularly. The mechanism of pain in thalassemia is associated with musculoskeletal disease. Arthropathy caused by iron accumulation can continue even though iron stores are normal. The number of ferritin levels can be disproportionate to the intensity of pain. ${ }^{28}$ There is a relationship between ferritin levels and pain that interferes with life because the pain in people with thalassemia is often chronic, so the intensity of pain, which is not too high, can interfere with the patient's quality of life. ${ }^{28}$ In addition, the pain intensity component has limitations in assessing chronic pain. It can be due to several factors. The objective assessment of pain is complex because pain is subjective. Acute pain can be considered adequate using a uni-dimensional pain screening tool, but a multidimensional pain screening tool is needed for chronic pain. Chronic pain is influenced by complex individual variations, despite getting the same exposure that can cause pain. The BPISF questionnaire is multidimensional, so from the results of a significant correlation on the dimensions of pain that interferes with life, it can be concluded that ferritin levels are correlated with pain. $.5,29$

\section{Conclusions}

There is a relationship between pain and serum ferritin levels in adults with TDT. Regular consumption of iron chelation tablets can reduce ferritin and improve the quality of life for adults with TDT. Therefore, it is necessary to regularly assess pain in adults with TDT and monitor serum ferritin levels.

\section{Conflict of Interest}

The authors declare no conflicts of interest in this study.

\section{Acknowledgments}

This research was funded by Competitive Internal Research Grant Universitas Padjadjaran (Academic Leadership Grant). Thank you, Research Center for Medical Genetics, for the facilitation, so the research was completed correctly.

\section{References}

1. Tubman VN, Fung EB, Vogiatzi M, Thompson AA, Rogers ZR, Neufeld EJ, et al. Guidelines for the standard monitoring of patients with thalassemia: report of the Thalassemia Longitudinal Cohort. J Pediatr Hematol Oncol. 2015;37(3):e162-9.

2. Galanello R, Origa R. Beta-thalassemia. Orphanet J Rare Dis. 2010;5:11.

3. Viprakasit V, Ekwattanakit S. Clinical classification, screening and diagnosis for thalassemia. Hematol Oncol Clin North Am. 2018;32(2)193-211.

4. Lal A. Assessment and treatment of pain in thalassemia. Ann N Y Acad Sci. 2016;1368(1): 65-72.

5. Halon-Golabek M, Borkowska A, HermanAntosiewicz A, Antosiewicz J. Iron metabolism of the skeletal muscle and neurodegeneration. Front Neurosci. 2019;13: 165.

6. $\mathrm{Fu} \mathrm{K}$, Robbins SR, McDougall JJ. Osteoarthritis: the genesis of pain. Rheumatology (Oxford). 2018;57(Suppl 4): iv43-50.

7. Cappellini MD, Cohen A, Porter J, Taher A, Viprakasit V. Guidelines for the management 
of transfusion dependent thalassaemia (TDT). $3^{\text {rd }}$ Edition. Nicosia: Thalassaemia International Federation; 2014.

8. Oliveros O, Trachtenberg F, Haines D, Gerstenberger E, Martin M, Carson S, et al. Pain over time and its effects on life in thalassemia. Am J Hematol. 2013;88(11): 939-43.

9. Whalen NL, Olynyk JK. Association of transferrin saturation with the arthropathy of hereditary hemochromatosis. Clin Gastroenterol Hepatol. 2017;15(10):1507-8.

10. Sawaya RA, Zahed L, Taher A. Peripheral neuropathy in thalassemia. Ann Saudi Med. 2006;26(5):358-63.

11. Tracey I, Woolf CJ, Andrews NA. Composite pain biomarker signatures for objective assessment and effective treatment. Neuron. 2019;101(5):783-800.

12. Goubert D, Meeus M, Willems T, De Pauw R, Coppieters I, Crombez $\mathrm{G}$ et al. The association between back muscle characteristics and pressure pain sensitivity in low back pain patients. Scand J Pain. 2018;18(2):281-93.

13. Cohen M, Quintner J, van Rysewyk S. Reconsidering the International Association for the Study of Pain definition of pain. Pain Rep. 2018;3(2):e634.

14. Perisano C, Marzetti E, Spinelli MS, Callà CAM, Graci C, Maccauro G. Physiopathology of bone modifications in $\beta$-thalassemia. Anemia. 2012;2012:320737.

15. Karimi M, Zarei T, Pishdad P. Extramedullary hematopoiesis in a patient with transfusion dependent beta-thalassemia presenting with cord compression. IJBC. 2018;10(1):28-30.

16. Moiz B, Khan HA, Raheem A, Shariq M. High prevalence of bone pain and fractures in young transfusion dependent patients with $\beta$-thalassemia at Southern Pakistan. Ann Hematol Oncol. 2019;6(2):1234.

17. Allegri M, Montella S, Salici F, Valente A, Marchesini M, Compagnone C, et al. Mechanism of low back pain: a guide for diagnosis and therapy. F10ooRes. 2016; 5(F10ooFaculty Rev):1530.

18. Wiitavaara B, Fahlström M, Djupsjöbacka M. Prevalence, diagnostics and management of musculoskeletal disorders in primary health care in Sweden - an investigation of 2000 randomly selected patient records. J Eval Clin Pract. 2017;23(2):325-32.

19. Primorac D, Molnar V, Rod E, Jeleč Z, Čukelj F, Matišić V, et al. Knee osteoarthritis: a review of pathogenesis and state-of-the-art non-operative therapeutic considerations. Genes (Basel). 2020;11(8):854.

20. Onwuasoanya A. Pain management and assessment for healthcare practitioners: review article. J Anesth Pain Med. 2016;1(2): oooo2.

21. Bonafé FSS, de Campos LA, Marôco J, Campos JADB. Brief Pain Inventory: a proposal to extend its clinical application. Eur J Pain. 2019;23(3):565-76.

22. Majedi H, Dehghani SS, Soleyman-Jahi S, Emami Meibodi SA, Mireskandari SM, Hajiaghababaei $M$, et al. Validation of the Persian version of the Brief Pain Inventory (BPI-P) in chronic pain Patients. J Pain Symptom Manage. 2017;54(1):132-8.

23. Poquet $\mathrm{N}$, Lin $\mathrm{C}$. The Brief Pain Inventory (BPI). J Physiother. 2016;62(1):52.

24. Oliveros O, Trachtenberg F, Haines D, Gerstenberger E, Martin M, Carson S, et al. Pain over time and its effects on life in thalassemia. Am J Hematol. 2013;88(11): 939-43.

25. Fraenkel L, Falzer P, Fried T, Kohler M, Peters E, Kerns R, et al. Measuring pain impact versus pain severity using a numeric rating scale. J Gen Intern Med. 2012;27(5):555-60.

26. Markman JD, Gewandter JS, Frazer ME. Comparison of a Pain Tolerability Question with the Numeric Rating Scale for assessment of self-reported chronic pain. JAMA Netw Open. 2020;3(4):e203155.

27. Bendinger $T$, Plunkett N. Measurement in pain medicine. BJA Educ. 2016;16(9):310-5.

28. Porter JL, Rawla P. Hemochromatosis. Treasure Island: StatPearls Publishing; 2020.

29. Bhardwaj P, Yadav R. Measuring pain in clinical trials: pain scales, endpoints, and challenges. Int $J$ Clin Exp Physiol. 2015;2(3):151-6. 